\title{
Expression and potential function of the CXC chemokine CXCL16 in pancreatic ductal adenocarcinoma
}

\author{
MORITZ N. WENTE ${ }^{1}$, MATTHIAS M. GAIDA ${ }^{1}$, CHRISTINE MAYER ${ }^{1}$, \\ CHRISTOPH W. MICHALSKI ${ }^{1,2}$, NATASCHA HAAG ${ }^{1}$, THOMAS GIESE ${ }^{3}$, \\ KLAUS FELIX ${ }^{1}$, FRANK BERGMANN ${ }^{4}$, NATHALIA A. GIESE ${ }^{1}$ and HELMUT FRIESS ${ }^{1,2}$ \\ ${ }^{1}$ Department of General Surgery, University of Heidelberg, Heidelberg; ${ }^{2}$ Department of Surgery, Technische Universität \\ München, Munich; Institutes of ${ }^{3} \mathrm{Immunology},{ }^{4}$ Pathology, University of Heidelberg, Heidelberg, Germany
}

Received February 20, 2008; Accepted April 22, 2008

DOI: 10.3892/ijo_00000009

\begin{abstract}
CXC chemokines have a major influence on the angiogenesis, growth and metastatic potential of pancreatic ductal adenocarcinoma. CXCL16 is a unique transmembrane CXC chemokine, which is shed by members of the disintegrins and metalloproteases (ADAMs), in particular by ADAM10 and ADAM17. In our study, we evaluated expression and potential function of CXCL16 and its receptor CXCR6. CXCL16 and the receptor CXCR6 are upregulated in pancreatic ductal adenocarcinoma (PDAC) and chronic pancreatitis tissues in contrast to normal pancreatic tissues at the mRNA and protein levels. In 85 and $100 \%$ of the investigated samples, tumor cells showed positive immunostaining for CXCL16 and CXCR6, respectively; furthermore, tubular complexes of chronic pancreatitis and the invasive front of PDAC were immunopositive for CXCL16 and CXCR6. Stimulation of PDAC cells with proinflammatory cytokines increased CXCL16 protein levels, whereas silencing of ADAM10 with siRNA transfection led to a decrease in CXCL16 protein levels in cell culture supernatants. No effects on cell viability were notable after incubation of cancer cells with CXCL16. However, CXCL16 markedly increased invasiveness of PDAC cells. Clinically, $82.5 \%$ of PDAC patients had higher CXCL16 serum values than the highest value seen in healthy donors. SELDI-TOF-MS analysis confirmed the upregulation of CXCL16 in sera of PDAC patients. In conclusion, CXCL16 in both transmembrane and soluble forms, and its receptor CXCR6, seem to play an important role in the pathobiology of pancreatic cancer and might be potential markers for pancreatic cancer diagnosis and a target for multimodal therapy concepts in the future.
\end{abstract}

Correspondence to: Dr Moritz N. Wente, Department of General Surgery, University of Heidelberg, D-69120 Heidelberg, Germany E-mail: moritz.wente@med.uni-heidelberg.de

Key words: pancreatic cancer, CXC chemokines, A disintegrin and metalloproteinase 10 , invasion

\section{Introduction}

Pancreatic ductal adenocarcinoma (PDAC) is one of the most aggressive human malignancies causing more than 30,000 deaths per year in the USA (1). Until today, all available treatment modalities, such as chemotherapy and radiotherapy, have had little impact on the clinical course of the disease (2). Thus, a better understanding of the molecular biology of PDAC is important for the development of potential additive and targeted therapy concepts and to establish novel detection markers (3-6).

Recently, interactions between the immune system and tumor cells have been thought to play a pivotal role in tumor progression $(7,8)$. In particular, in pancreatic cancer, the microenvironment with its distinct inflammatory reaction plays an active role in the progression of the disease $(9,10)$. Recent findings have demonstrated that tumor cells themselves produce cytokines and chemokines, thereby leading to a modulation of their microenvironment and protecting tumor cells from immune cell-mediated attacks $(11,12)$.

The functions of chemokines, and in particular, of CXC chemokines, have been of increasing interest in a variety of malignant disorders $(13,14)$. CXC chemokines and their corresponding receptors have been identified as playing an important role in the regulation of angiogenesis, growth, invasiveness and metastasis of tumors (15-17). Only limited data have been published on the function of the until now 16 known CXC chemokines (CXCL1-CXCL16) and their seven corresponding CXC receptors (CXCR1-CXCR7) in PDAC $(18,19)$. So far, the axes CXCL8 with CXCR2 and CXCL12 with CXCR4 have been described as key regulators in angiogenesis and tumor metastasis in pancreatic cancer (20-24). Recently, the upregulation of CXCL14 in pancreatic cancer and its role in increasing invasiveness has been described (25).

In 2000, Matloubian et al described a novel member of the CXC chemokine family: the transmembrane chemokine CXCL16/SR-PSOX as a ligand for the HIV-coreceptor CXCR6/ Bonzo (26). Expression of CXCL16 is inducible by proinflammatory cytokines, such as tumor necrosis factor $\alpha(\mathrm{TNF} \alpha)$ and interferon $\gamma(\mathrm{IFN} \gamma)$ and exists both in a transmembrane bound form and as soluble CXCL16, where the soluble form is shed from the cell surface by the metalloproteinases ADAM10 and ADAM17 (27). 
CXCL16 plays a role as a cell adhesion molecule by binding its receptor CXCR6, expressed on activated T-cells and bone marrow plasma cells (28). The soluble form of CXCL16 is an active player in the chemotaxis of CXCR6expressing lymphocytes (29).

So far, there is only limited knowledge as to the role of the CXCL16 ligand and CXCR6 receptor axis in malignant diseases. Ludwig et al demonstrated that CXCL16 is overexpressed by reactive astrocytes and glioma cells, further inducible by TNF $\alpha$ and IFN $\gamma$ and that CXCL16 is shed from glial cells by ADAM10 and ADAM17 (30). Both are members of the disintegrin-like metalloproteinase family and have pro-proliferative effects on CXCR6-positive glial cells (30). Wagsater et al first described a suppression of CXCL16 protein in a small number of human rectal cancer tissues, but no downregulation of CXCL16 on the mRNA level (31). More recently, Hojo et al evaluated the role of CXCL16 in colorectal cancer in more detail: colorectal cancer tissues showed consistently upregulated CXCL16 expression compared to normal mucosa from the same patients. Furthermore, high CXCL16 expression significantly correlated with a high level of tumor-infiltrating lymphocytes and in particular with a better prognosis for colorectal cancer (32).

The expression and role of CXCL16 and its corresponding receptor CXCR6, in pancreatic disease is still unknown. Therefore, the aim of the present study was to evaluate the expression and potential function of CXCL16 and CXCR6 in the pathophysiology of PDAC.

\section{Materials and methods}

Patients and specimen collection. Pancreatic tissue samples were obtained from patients who underwent pancreatic resections for pancreatic ductal adenocarcinoma (PDAC) or chronic pancreatitis (CP). Pancreas tissue from healthy donors was collected through an organ donor program whenever there was no suitable recipient. The diagnosis of all samples was confirmed histologically.

For RNA extraction or protein isolation, tissue samples were snap-frozen in liquid nitrogen and stored at $-80^{\circ} \mathrm{C}$ until use or preserved in RNAlater (Ambion Europe, Huntington, UK). For immunohistochemical analysis, samples were fixed in $4 \%$ formalin solution for 18-24 $\mathrm{h}$ and subsequently embedded in paraffin. Serum samples were obtained from patients with PDAC and CP preoperatively, whereas control samples were obtained from healthy volunteers. Fresh blood samples were immediately centrifuged and supernatants were kept frozen at $-80^{\circ} \mathrm{C}$ until use.

The use of the clinical samples for analysis was approved by the Ethics Committee of the University of Heidelberg and written informed consent was obtained from the patients.

Quantitative real-time polymerase chain reaction ( $q R T-P C R)$ analysis. All reagents and equipment for mRNA/cDNA preparation were purchased from Roche Applied Sciences (Mannheim, Germany). Automated mRNA preparation was carried out using a MagNA PURE LC instrument and corresponding isolation kit I (for cells) and kit II (for tissue samples). Primers were obtained from Search-LC (Heidelberg, Germany). By using a 1st Strand cDNA Synthesis Kit, cDNA for RT-PCR was prepared, and RT-PCR performed with the LightCycler-FastStart DNA SYBR Green kit according to the manufacturer's instructions. The number of specific CXCL16, CXCR6 and ADAM10 transcripts were normalized to the housekeeping gene cyclophilin-B (CPB) and presented as adjusted copies/10k copies CPB, as described previously (33).

Cell lines. Four human pancreatic cancer cell lines were used: BxPC3 and CAPAN-1 were purchased from American Type Culture Collection (ATCC, Rockville, MD, USA) and COLO-357 and T3M4 were a gift from R. S. Metzgar (Duke University, Durham, NC, USA). Cells were grown in RPMI-1640 medium containing 10\% fetal bovine serum (FBS), $100 \mathrm{U} / \mathrm{ml}$ penicillin and $100 \mu \mathrm{g} / \mathrm{ml}$ streptomycin (Invitrogen, Karlsruhe, Germany) and were incubated at $37^{\circ} \mathrm{C}$ in a $5 \% \mathrm{CO}_{2}$ humidified atmosphere.

Immunoblot analysis. Proteins were extracted from pancreatic tissues and cell lines (BxPC3, T3M4, CAPAN-1, COLO-357). Protein concentration was measured with the micro-BCA protein assay (Perbio, Bonn, Germany). Tissue or cellular protein lysates $(25 \mu \mathrm{g})$ and $75 \mu \mathrm{g}$ of spleen tissue serving as a positive control, were separated by electrophoresis in $10-12 \%$ Bis-Tris gels (Invitrogen), transferred to nitrocellulose membrane and blocked with 5\% non-fat dry milk in TTBS (20 mM Tris- $\mathrm{HCl}, 150 \mathrm{mM} \mathrm{NaCl}$, and $0.1 \%$ Tween-20; 5\% M-TTBS) for $1 \mathrm{~h}$. The membranes were incubated overnight at $4^{\circ} \mathrm{C}$ with goat anti-human CXCL16 (R\&D Systems, Wiesbaden, Germany) or rabbit anti-human CXCR6 (ProSci, Poway, CA, USA), diluted 1:500 in 5\% M-TTBS. The next day, membranes were washed with TTBS, and blocked for $1 \mathrm{~h}$ with 5\% M-TTBS. Membranes were incubated for $1 \mathrm{~h}$ with the secondary antibody at room temperature. Horseradish peroxidase-conjugated anti-goat (Amersham Life Science, Amersham, UK) or horseradish peroxidase-conjugated anti-rabbit (Santa Cruz Biotechnologies, Santa Cruz, CA, USA) antibodies were used. Signal detection was performed by using an enhanced chemiluminescence reaction (ECL Western blotting detection; Amersham). Simply Blue SafeStain (Invitrogen) was applied to assess the equivalence of sample loading.

Immunohistochemistry. Paraffin-embedded tissues from pancreatic cancer $(n=20)$, chronic pancreatitis $(n=22)$, and healthy donors $(\mathrm{n}=11)$ were cut into $3-\mu \mathrm{m}$ sections which were used for analysis. For immunostaining, the Dako+ EnVision System (Dako Cytomation, Hamburg, Germany) was used. After deparaffinization, slides were incubated for $10 \mathrm{~min}$ in $0.3 \%$ hydrogen peroxidase to block endogenous peroxidase activity. Then, the sections were incubated for $30 \mathrm{~min}$ at room temperature with normal goat serum or normal rabbit serum prior to overnight incubation at $4{ }^{\circ} \mathrm{C}$ with monoclonal mouse-anti-human CXCR6 (1:400) or polyclonal goat anti-human CXCL16 (1:40) antibodies (R\&D Systems). The next day, after washing 3 times with TBS/0.1\% BSA$0.5 \%$ Tween-20, slides were incubated with a goat antimouse secondary antibody solution (Dako Cytomation) or rabbit anti-goat IgG (Sigma-Aldrich, Taufkirchen, Germany) diluted $1: 1000$ in $1 \mathrm{X} \mathrm{TBS} / 0.1 \% \mathrm{BSA}$ for $45 \mathrm{~min}$ at room 
temperature. For the following colour-reaction, Dako DAB+ Chromogen K3468 was used according to the manufacturer's protocol. Slides were counterstained with Mayer's hematoxylin. The sections were washed and mounted with xylenebased mounting medium. For semiquantitative analysis, slides were scored by two observers. Since the staining pattern within each sample was generally homogenous, staining of the cancer cells in each sample was categorized as absent, weak, moderate or strong. In the case of divergent scoring, a third observer decided upon the final category.

Cell proliferation assays (MTT assay and CV assay). The 3-(4,5-methylthiazol-2yl)-2,-5-diphenyl-tetrazoliumbromide (MTT) (Sigma-Aldrich) and the crystal violet (CV) (SigmaAldrich) assays were used to assess cell proliferation. The cells (BxPC3, T3M4, CAPAN-1, COLO-357) were seeded in 96-well plates at a density of $5 \times 10^{3}$ cells/well in $100 \mu 1$ of complete medium and grown overnight. Then, $100 \mu 1$ of RPMI, containing different concentrations of recombinant human CXCL16 (R\&D Systems) with final concentrations of $2.5,5,10,25,50$ or $100 \mathrm{ng} / \mathrm{ml}$ or control were added.

After 48 or $72 \mathrm{~h}$ of incubation, MTT was added to a final concentration of $0.5 \mathrm{mg} / \mathrm{ml}$ and incubated for $4 \mathrm{~h}$. The supernatants were removed, the plates were dried for $3 \mathrm{~h}$ at room temperature and $100 \mu \mathrm{l} /$ well acidic isopropanol was added. For crystal violet assays, after 48 or $72 \mathrm{~h}$ of incubation supernatant was discarded and $100 \mu \mathrm{l} /$ well $\mathrm{CV}$ was added and incubated for $15 \mathrm{~min}$. The plates were then washed in tap water and air dried for $3 \mathrm{~h}$. To dissolve the dye, $100 \mu \mathrm{l} /$ well methanol was added.

The optical densities (OD) were measured at $570 \mathrm{~nm}$ to compare treatment and control groups. The experiments were carried out in triplicate and repeated three times.

Matrigel invasion assay. Invasion assays were performed using a standardized Matrigel invasion chamber (Biocoat Matrigel invasion chamber, $8-\mu \mathrm{m}$ pore size; BD Biosciences, Heidelberg, Germany) according to the manufacturer's instructions. First, the Matrigel membrane was rehydrated with $500 \mu 1$ serum-free RPMI-medium and incubated at $37^{\circ} \mathrm{C}$ in a $5 \% \mathrm{CO}_{2}$ humidified atmosphere for $2 \mathrm{~h}$. Then, BxPC-3 or T3M4 cells $\left(5 \times 10^{4}\right.$ cells $\left./ \mathrm{ml}\right)$ were seeded in RPMI medium containing 1\% FBS. CXCL16 (R\&D Systems) was added into the lower chamber at a final concentration of $25 \mathrm{ng} / \mathrm{ml}$ and further incubated for $48 \mathrm{~h}$. Non-invading cells were removed from the upper surface of the membrane using a cotton-tipped swab before membranes were fixed for $20 \mathrm{~min}$ in ice-cold methanol. Subsequently, invading cells were stained with $1 \%$ toluidine blue (Sigma-Aldrich, Taufkirchen, Germany). To calculate the total number of invading cells, the cell number in the complete membrane cutout (membrane surface area $0.3 \mathrm{~cm}^{2}$ ) was counted. The assay was performed in duplicate and repeated three times.

Stimulation assays with proinflammatory cytokines (TNF $\alpha$ and $I F N \gamma)$. Stimulation assays were performed by seeding $2.5 \times 10^{5}$ cells (BxPC3, T3M4, CAPAN-1, COLO-357) in 6 -well plates and growing them overnight. Then, the supernatant was discarded and replaced by fresh RPMI-1640 medium containing $1 \mathrm{ng} / \mathrm{ml}$ of $\mathrm{TNF} \alpha, 1 \mathrm{ng} / \mathrm{ml} \mathrm{IFN} \gamma$ or a combination of both cytokines (R\&D Systems); PBS + $0.1 \%$ BSA was used as a control (Sigma-Aldrich) After $24 \mathrm{~h}$ of incubation, supernatants were collected and CXCL16 concentrations were measured using a commercially available ELISA kit (CXCL16 Quantikine ELISA Kit, R\&D Systems) according to the manufacturer's instructions. All samples were measured at least in duplicate.

siRNA transfection for silencing ADAM10. Cells were transfected with two different ADAM10 siRNA oligonucleotides, labeled siRNA1 (Ambion Applied Biosystems, Darmstadt, Germany) and siRNA2 (Qiagen, Hilden, Germany) or control siRNA oligonucleotides (Negative Control siRNA, Qiagen) using $15 \mu \mathrm{l}$ of transfection reagent (RNAiFect Transfection Reagent, Qiagen) according to the manufacturer's instructions. The sequences were: siRNA1 sense GGA UAA CAG AGA AUG GUG Gtt, siRNA 1 antisense CCA CCA UUC UCU GUU AUC Ctg; siRNA2 sense CAA ACU UCA CAG ACU GUA Att, siRNA2 antisense UUA CAG UCU GUG AAG UUU Ggt; control siRNA sense UUC UCC GAA CGU GUC ACG Utt, control siRNA antisense ACG UGA CAC GUU CGG AGA Att. Briefly, 2x105 PDAC cells (BxPC3 and COLO-357) were seeded in 6-well plates and subsequently transfected with the indicated siRNA (100 $\mu 1$ transfection solution containing $5 \mu \mathrm{g}$ ADAM10 siRNA or $5 \mu \mathrm{g}$ control siRNA). After $24 \mathrm{~h}$, medium was replaced by serum-free medium. Successful siRNA transfection was confirmed by qRT-PCR of ADAM10 transcripts after a total transfection time of $48 \mathrm{~h}$. In addition, after transfection for $24 \mathrm{~h}(24 \mathrm{~h}$ after medium replacement) cell culture supernatants were collected, centrifuged and CXCL16 ELISA (R\&D Systems) was performed according to the manufacturer's instructions.

Serum ELISA. CXCL16 levels in cell culture supernatants and serum samples of patients with PDAC $(n=80), C P$ $(n=20)$, and from healthy donors $(n=20)$ serving as controls were measured using a commercially available ELISA kit (see above) according to the manufacturer's instructions. All samples were at least measured in duplicate.

SELDI-TOF-MS analysis. In order to evaluate the integrity and size of the soluble or shedded CXCL16 forms detected in patient serum by ELISA, mass spectrometry analysis of proteins was performed with the SELDI-TOF-MS ProteinChip Biology System IIc (PBS IIc) (Ciphergen Biosystems, Fremont, CA, USA), as described previously (34). Briefly, prior to protein analysis, the PBS IIc Proteinchip Reader instrument was externally calibrated using the all-in-one protein molecular mass standard (Ciphergen Biosystems).

NP20 ProteinChip array. Arrays were prepared according to the manufacturer's guidelines (Ciphergen Biosystems). Two microliters of analyte were added to the spot containing either: recombinant CXCL16 containing 10, 5, 2, 1, 0.5, and $0.1 \mathrm{ng}$ to monitor the detection limit or Protein G (Sigma, St. Louis, MI, USA) or anti-human CXCL16 antibody to monitor the purity and quality of the two proteins. The spots were air dried and an energy absorption matrix $0.8 \mu 1$ sinapinic acid solution $(50 \% \mathrm{v} / \mathrm{v}$ acetonitrile, $0.5 \% \mathrm{v} / \mathrm{v}$ trifluoroacetic acid in $\mathrm{H}_{2} \mathrm{O}$ ) applied twice per spot. 
A

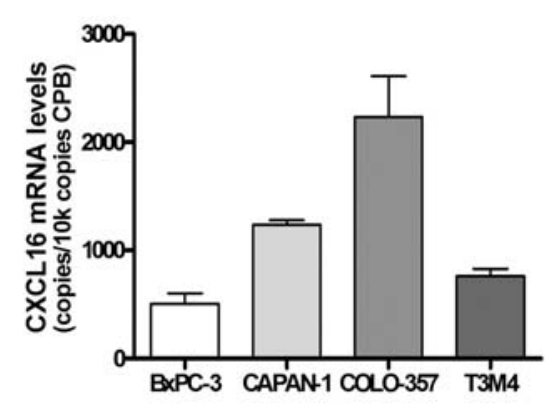

C

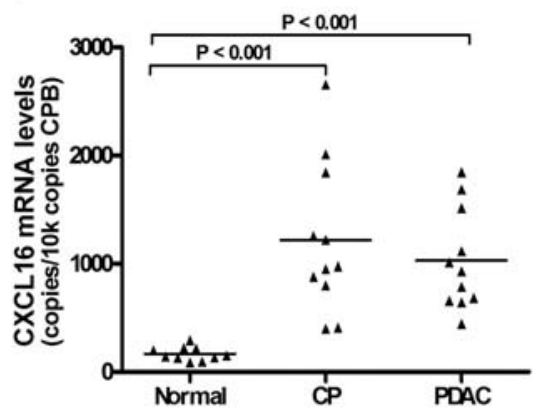

B

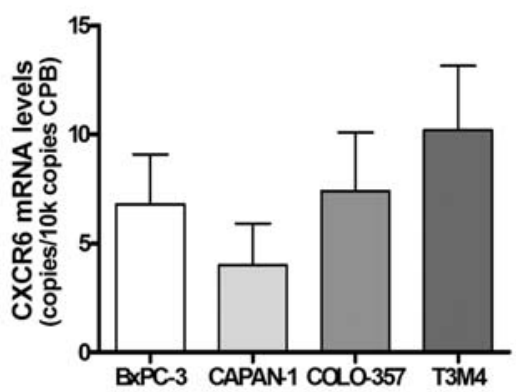

D

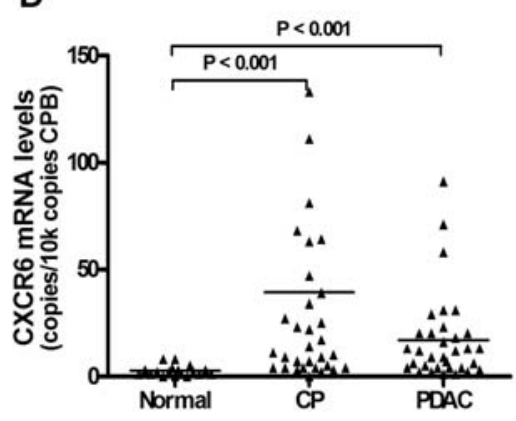

Figure 1. Expression of CXCL16 and CXCR6 mRNA in pancreatic cancer (PDAC) cells and pancreatic tissues (qRT-PCR). (A) CXCL16 and (B) CXCR6 mRNA expression levels in pancreatic cancer cell lines. (C) CXCL16 mRNA expression levels in normal pancreas $(\mathrm{n}=10)$, chronic pancreatitis $(\mathrm{CP})(\mathrm{n}=11)$, and PDAC tissue $(\mathrm{n}=11)$; $(\mathrm{P}<0.001$ PDAC versus normal, $\mathrm{P}<0.001$ PDAC versus $\mathrm{CP})$. (D) CXCR6 mRNA expression levels in normal pancreas ( $\mathrm{n}=18), \mathrm{CP}$ $(\mathrm{n}=32)$, and $\mathrm{PDAC}$ tissue $(\mathrm{n}=33)$; $(\mathrm{P}<0.001 \mathrm{PDAC}$ versus normal, $\mathrm{P}<0.001$ PDAC versus $\mathrm{CP})$.

A

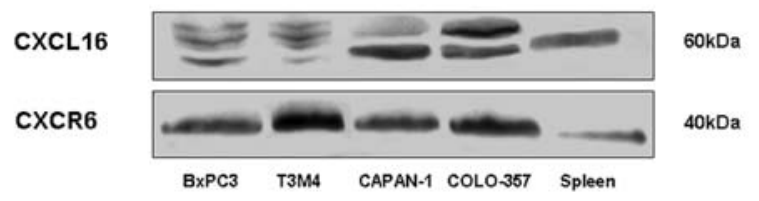

B

CXCL16

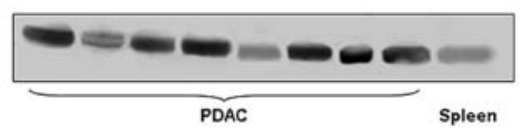

CXCL16

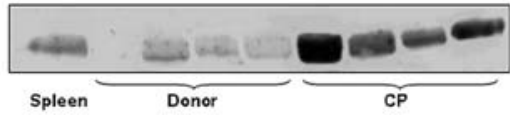

$60 \mathrm{kDa}$

Figure 2. Expression of CXCL16 and CXCR6 protein in pancreatic cancer (PDAC) cells and pancreatic tissues. (A) CXCL16 and CXCR6 protein expression in pancreatic cancer cell lines. All tested cell lines displayed protein expression for CXCL16 (upper panel) and CXCR6 (lower panel). Spleen lysate served as a positive control. (B) CXCL16 protein expression in normal pancreas $(n=4)$ and chronic pancreatitis $(C P)(n=4)$ (lower panel), and pancreatic cancer (PDAC) tissue $(\mathrm{n}=8)$ (upper panel). Spleen lysate served as a positive control. In line with the results of the qRT-PCR, there is upregulated expression of CXCL16 protein in CP as well as in PDAC compared to normal pancreas. CXCR6 was not detectable in human tissue samples at the protein level using immunoblotting.

PS20 ProteinChip array preparation. Preactivated surface protein chips PS20 (Ciphergen Biosystems) were prepared as follows: Protein $\mathrm{G}$ was reconstituted in PBS, $\mathrm{pH} 8.6$
$(200 \mu \mathrm{g} / \mathrm{ml})$ and $3 \mu 1(600 \mathrm{ng})$ were added per spot. After $2 \mathrm{~h}$ of coupling in a humidified chamber the residual volume was shaken off and the inactivation of the unoccupied epoxide sides was performed by pipetting $6 \mu 1$ of $0.5 \mathrm{M}$ Tris $/ \mathrm{HCl}, \mathrm{pH} 8$ on each spot and incubating for $30 \mathrm{~min}$ at room temperature. Two wash steps with PBS followed and the chips were loaded with $5 \mu 1$ anti-human CXCL16 antibody and incubated in a humid chamber for $3 \mathrm{~h}$ at room temperature. Afterwards the spots were washed with $6 \mu 1$ of $0.5 \mathrm{M}$ Tris/ $\mathrm{HCl}, \mathrm{pH} 8.0$ followed by wash buffer (100 mM Na-phosphate $\mathrm{pH} 7.4$, $0.5 \mathrm{M} \mathrm{NaCl}$ and $0.05 \%$ Triton). The chips were then loaded with PBS diluted CXCL16 or with $8 \mu 1$ serum from PDAC and controls (1:2 dilution) and incubated overnight at $4^{\circ} \mathrm{C}$. Unbound protein and salts were removed by washing the chips thrice with wash buffer and twice with deionized water. Finally, $1.0 \mu 1$ sinapinic acid solution $(50 \% \mathrm{v} / \mathrm{v}$ acetonitrile, $0.5 \% \mathrm{v} / \mathrm{v}$ trifluoroacetic acid in $\mathrm{H}_{2} \mathrm{O}$ ) was applied twice per spot and the air-dried chips stored at room temperature.

Statistical analysis. Statistical analysis was performed using GraphPad Prism 4 Software (GraphPad, San Diego, CA). The Mann-Whitney U test or analysis of variance (KruskalWallis test), followed by a post hoc Dunn's multiple comparison test were performed where appropriate. Significance was defined as $\mathrm{P}<0.05$.

\section{Results}

Expression of CXCL16 and CXCR6 in PDAC cells and pancreatic tissues. CXCL16 and CXCR6 mRNA expression was detected by qRT-PCR in all tested PDAC cell lines. 
Table IA. Semiquantitative analysis of CXCL16 immunoreactivity in pancreatic cancer (PDAC), chronic pancreatitis (CP) and normal pancreas (Donor) tissues.

\begin{tabular}{|c|c|c|c|c|}
\hline CXCL16 tissue & $\begin{array}{c}\text { Diffuse } \\
\text { stains }\end{array}$ & $\begin{array}{l}\text { Focal } \\
\text { stains }\end{array}$ & $\begin{array}{l}\text { Negative } \\
\text { stains }\end{array}$ & $\mathrm{n}^{\mathrm{a}}$ \\
\hline \multicolumn{5}{|l|}{ PDAC (n=20) } \\
\hline Cancer cells & 3 & 14 & 3 & 20 \\
\hline Tubular complexes & 7 & 1 & 0 & 8 \\
\hline Exocrine cells & 4 & 4 & 2 & 10 \\
\hline Islets & 9 & 0 & 5 & 14 \\
\hline Ducts & 12 & 1 & 2 & 15 \\
\hline Vessels & 15 & 1 & 4 & 20 \\
\hline Nerves & 4 & 4 & 11 & 19 \\
\hline Stroma & 2 & 3 & 14 & 19 \\
\hline Immune cells & 0 & 18 & 2 & 20 \\
\hline \multicolumn{5}{|l|}{$\mathrm{CP}(\mathrm{n}=22)$} \\
\hline Tubular complexes & 14 & 3 & 0 & 17 \\
\hline Exocrine cells & 8 & 8 & 2 & 18 \\
\hline Islets & 7 & 1 & 10 & 18 \\
\hline Ducts & 16 & 4 & 0 & 20 \\
\hline Vessels & 9 & 3 & 10 & 22 \\
\hline Nerves & 11 & 3 & 8 & 22 \\
\hline Stroma & 2 & 2 & 16 & 20 \\
\hline Immune cells & 0 & 19 & 3 & 22 \\
\hline \multicolumn{5}{|l|}{ Donor $(n=11)$} \\
\hline Exocrine cells & 0 & 2 & 9 & 11 \\
\hline Islets & 0 & 0 & 11 & 11 \\
\hline Ducts & 2 & 4 & 5 & 11 \\
\hline Vessels & 2 & 3 & 6 & 11 \\
\hline Nerves & 0 & 1 & 10 & 11 \\
\hline Stroma & 0 & 0 & 0 & 0 \\
\hline Immune cells & 0 & 1 & 0 & 1 \\
\hline
\end{tabular}

${ }^{a}$ Number available.

Expression of CXCL16 was markedly high with copy numbers between mean $505.7 \pm 97.5$ and $2236.0 \pm 374.3$ copies/10k copies CPB in BxPC-3 and COLO-357 cells, respectively (Fig. 1A). Expression of CXCR6 mRNA was detected in all cell lines with low copy numbers between $4.0 \pm 1.9$ and $7.4 \pm 2.7$ copies/10k copies CPB in CAPAN-1 and COLO-357 cells, respectively (Fig. 1B).

To compare the in vivo expression profile of CXCL16 and CXCR6 in the normal and diseased pancreas, qRT-PCR was performed using RNA isolated from PDAC, CP, and normal pancreas from organ donors. This analysis revealed a significant increase in CXCL16 mRNA levels in PDAC with $1028.0 \pm 140.2$ copies/10k copies CPB and CP with $1217.0 \pm 209.7$ copies/10k copies CPB compared to normal pancreas with $164.8 \pm 20.3$ copies/10k copies CPB, respectively $(\mathrm{P}<0.001$; PDAC vs. normal, 6.2-fold increase and $\mathrm{CP}$ vs. normal, 7.4-fold increase, respectively; Fig. 1C). There was an increase in CXCR6 mRNA levels in PDAC with $17.0 \pm 3.6$ copies/10k copies CPB and CP with $39.3 \pm 13.1$
Table IB. Semiquantitative analysis of CXCR6 immunoreactivity in pancreatic cancer (PDAC), chronic pancreatitis (CP) and normal pancreas (Donor) tissues.

\begin{tabular}{|c|c|c|c|c|}
\hline CXCR6 Tissue & $\begin{array}{l}\text { Diffuse } \\
\text { stains }\end{array}$ & $\begin{array}{l}\text { Focal } \\
\text { stains }\end{array}$ & $\begin{array}{l}\text { Negative } \\
\text { stains }\end{array}$ & $\mathrm{n}^{\mathrm{a}}$ \\
\hline \multicolumn{5}{|l|}{ PDAC (n=20) } \\
\hline Cancer cells & 10 & 10 & 0 & 20 \\
\hline Tubular complexes & 7 & 0 & 0 & 7 \\
\hline Exocrine cells & 10 & 0 & 0 & 10 \\
\hline Islets & 13 & 0 & 0 & 13 \\
\hline Ducts & 5 & 8 & 0 & 13 \\
\hline Vessels & 12 & 8 & 0 & 20 \\
\hline Nerves & 19 & 0 & 0 & 19 \\
\hline Stroma & 7 & 12 & 0 & 19 \\
\hline Immune cells & 0 & 20 & 0 & 20 \\
\hline \multicolumn{5}{|l|}{$\mathrm{CP}(\mathrm{n}=22)$} \\
\hline Tubular complexes & 8 & 2 & 0 & 10 \\
\hline Exocrine cells & 14 & 5 & 0 & 19 \\
\hline Islets & 10 & 4 & 0 & 14 \\
\hline Ducts & 2 & 16 & 1 & 19 \\
\hline Vessels & 1 & 19 & 2 & 22 \\
\hline Nerves & 16 & 6 & 0 & 22 \\
\hline Stroma & 9 & 9 & 0 & 18 \\
\hline Immune cells & 1 & 20 & 1 & 22 \\
\hline \multicolumn{5}{|l|}{ Donor $(n=11)$} \\
\hline Exocrine cells & 6 & 4 & 1 & 11 \\
\hline Islets & 9 & 0 & 1 & 10 \\
\hline Ducts & 0 & 11 & 0 & 11 \\
\hline Vessels & 0 & 10 & 0 & 10 \\
\hline Nerves & 9 & 0 & 1 & 10 \\
\hline Stroma & 0 & 1 & 0 & 1 \\
\hline Immune cells & 0 & 3 & 0 & 3 \\
\hline
\end{tabular}

${ }^{a}$ Number available.

copies/10k copies CPB compared to normal pancreas with $2.5 \pm 0.6$ copies $/ 10 \mathrm{k}$ copies $\mathrm{CPB}$, respectively $(\mathrm{P}<0.001$ PDAC vs. normal, 6.8-fold increase and CP vs. normal, 15.6fold increase, respectively; Fig. 1D).

Analysis of CXCL16 and CXCR6 protein levels was performed by immunoblotting. In all cell lines, CXCL16 as well as CXCR6 was detectable on the protein level (Fig. 2A). To analyze whether increased CXCL16 mRNA levels would also result in increased protein levels, immunoblot analysis was carried out. CXCL16 was weakly expressed in normal pancreas as a $60-\mathrm{kDa}$ protein. In line with the qRT-PCR data there was an increased expression of CXCL16 in CP and PDAC tissues compared to normal pancreas (Fig. 2B). CXCR6 was not detectable in tissue samples using immunoblotting.

Subsequent evaluation of CXCL16 and CXCR6 immunoreactivity revealed differences between pancreatic cancer, chronic pancreatitis and normal pancreas tissue; semiquantitative analyses of the immunohistochemistry results are given in tabular form (CXCL16 Table IA, CXCR6 Table IB). 

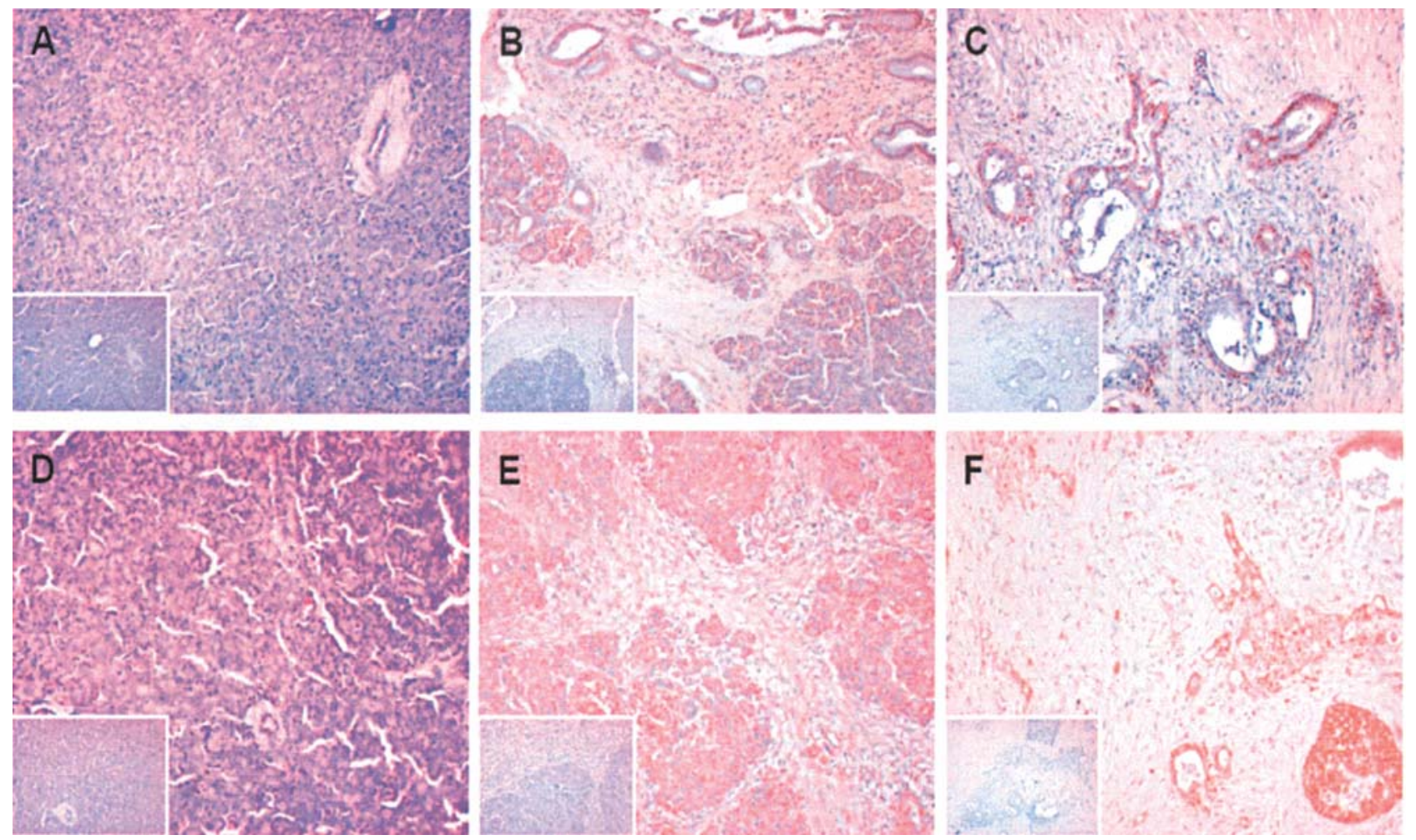

Figure 3. Expression and localization of CXCL16 and CXCR6 in pancreatic tissues. Immunohistochemistry was performed as described in Materials and methods. CXCL16 immunoreaction in normal pancreas (A), chronic pancreatitis (CP) (B), and pancreatic cancer (PDAC) (C). CXCR6 immunoreaction in normal pancreas (D), CP (E), PDAC (F). Note the negative immunoreactivity in consecutive negative control tissue sections (inserts). The given slides reveal representative examples of the immunohistochemistry of CXCL16 and CXCR6.

A

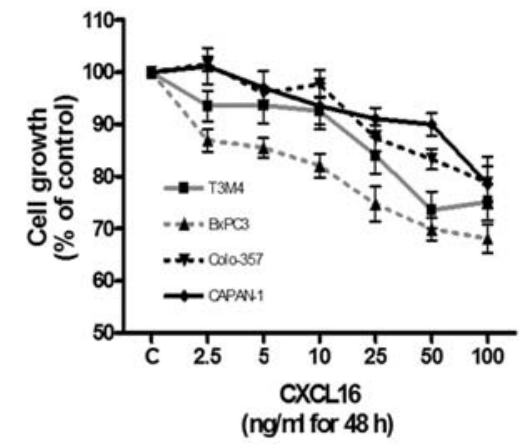

B

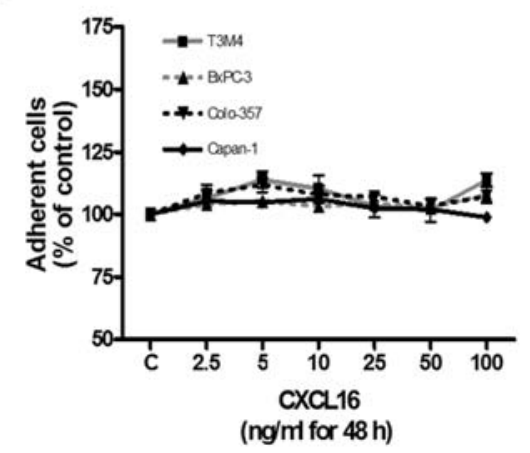

C

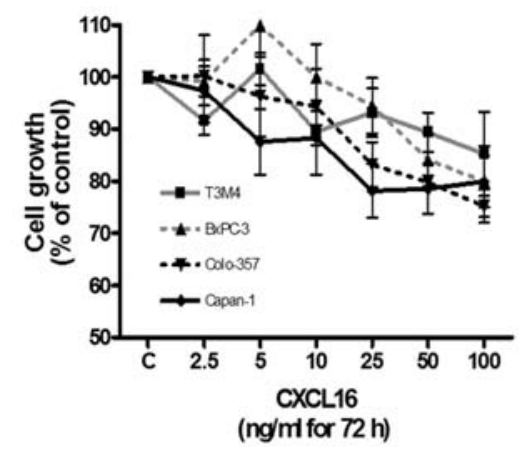

D

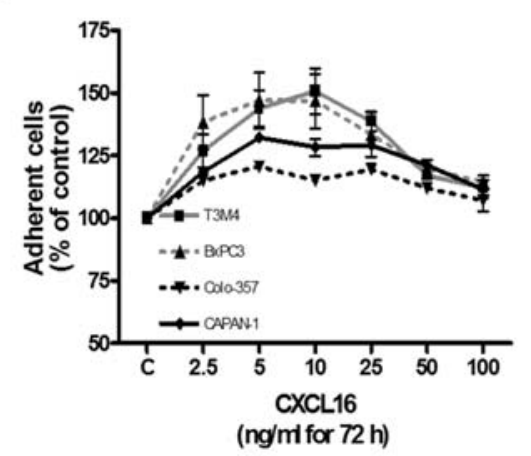

Figure 4. Effect of CXCL16 on pancreatic cancer cell growth. The indicated pancreatic cancer cells were treated with 2.5, 5, 10, 25, 50, and 100 ng/ml CXCL16. MTT assays (A, B) and CV assays (C, D) were performed after incubation for 48 and $72 \mathrm{~h}$, respectively, as described in Materials and methods. Data are presented as mean \pm SEM of three independent experiments. 
A

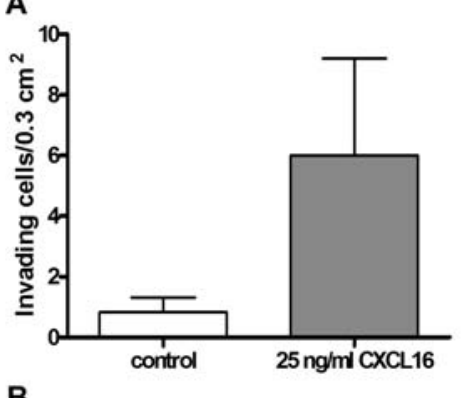

B

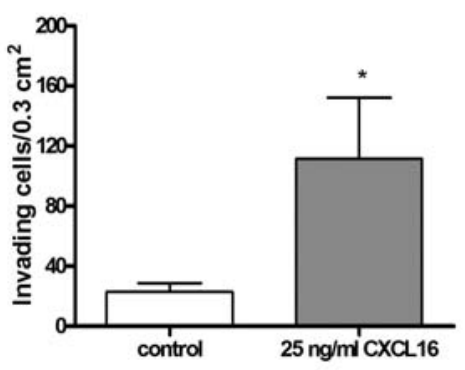

Figure 5. Effect of stimulation with CXCL16 on invasiveness of pancreatic cancer cells. Invasiveness of T3M4 (A) and BxPC3 (B) pancreatic cancer cells, assayed by a standardized Matrigel assay as described in Materials and methods, was increased by treatment with $25 \mathrm{ng} / \mathrm{ml} \mathrm{CXCL16}$ for $48 \mathrm{~h}$ $\left({ }^{*} \mathrm{P}<0.05\right.$ versus control). Data are presented as mean $\pm \mathrm{SEM}$ of three independent experiments; membrane surface area, $0.3 \mathrm{~cm}^{2}$.

In $85 \%$ of pancreatic cancer tissues, tumor cells revealed a positive staining for CXCL16. In addition, peritumoral parenchyma altered by inflammation, revealed a strong immunohistochemical positivity for CXCL16. In chronic pancreatitis specimens, intense CXCL16 immunostaining was particularly found in tissue remodeled by inflammatory processes. Furthermore, ducts, nerves and infiltrating inflammatory cells were immunopositive for CXCL16. Normal acinar cells showed faint immunoreactivity in only a few cases (Fig. 3A-C).

CXCR6 was immunohistochemically detected in the tumor cells of all pancreatic cancer specimens. Furthermore, inflammatory altered pancreatic parenchyma consistently revealed a strong CXCR6 expression. CXCR6 expression was also found in nerves and infiltrating inflammatory cells. In chronic pancreatitis specimens, inflammatory remodelled pancreatic tissue and nerves revealed positive immunostaining. However, normal acinar cells obtained from organ donors showed only very faint, focal immunoreactivity (Fig. 3D-F).

Effect of CXCL16 on cell growth and invasiveness of PDAC cells. A variety of CXC chemokines, such as CXCL1 and CXCL8, have been shown to have proliferative effects on PDAC cells $(35,36)$. In addition, the members of the CXC chemokine family CXCL8, CXCL12, and CXCL14 are potent inducers of PDAC cell invasiveness $(21,25,37)$. CXCL16 has been shown to have proliferative effects on, and increase invasiveness of trophoblasts (38).

To evaluate potential effects of CXCL16 on pancreatic cancer growth, standardized MTT and crystal violet (CV) assays were performed in four different pancreatic cancer cell lines in a dose- and time-dependent manner.
In MTT assays based on mitochondrial activity of the cells, no substantial effects of CXCL16 on cell viability in all tested cell lines up to concentrations of $25 \mathrm{ng} / \mathrm{ml} \mathrm{CXCL16}$ after incubation for 48 and $72 \mathrm{~h}$ were recognized. Higher doses of CXCL16 up to $100 \mathrm{ng} / \mathrm{ml}$ showed a toxic effect with a decrease of cell growth in all tested cell lines (Fig. 4A and B).

In contrast, $\mathrm{CV}$ assays based on the amount of adherent cells showed no effect of CXCL16 on cell growth after incubation for $48 \mathrm{~h}$. Longer incubation for $72 \mathrm{~h}$ revealed a trend towards an increased number of cells, in particular in T3M4 and BxPC3 cells, in the range of 5-25 ng/ml CXCL16 (Fig. 4C and D).

A potential effect of CXCL16 on the invasive capacity of pancreatic cancer cells was tested by standardized Matrigel invasion assays. BxPC3 and T3M4 cells were incubated with $25 \mathrm{ng} / \mathrm{ml}$ exogenous CXCL16 for $48 \mathrm{~h}$; this concentration of CXCL16 revealed no significant effects on cell proliferation in MTT and CV assays. CXCL16 increased the invasiveness of pancreatic cancer cells as compared with the control. T3M4 cells showed only limited invasive capacity overall (Fig. 5A). In contrast, exogenous CXCL16 significantly increased the invasive capacity of BxPC3 cells $(25 \mathrm{ng} / \mathrm{ml}$ CXCL16: $111.3 \pm 40.8$ versus control: $22.8 \pm 5.9$ invading cells, respectively; $\mathrm{P}=0.02$ ) (Fig. 5B).

Regulation of CXCL16 expression in PDAC cells. CXCL16 expression is inducible by stimulation with proinflammatory cytokines, in particular $\mathrm{TNF} \alpha$ and $\operatorname{IFN} \gamma(27,39)$. Membranebound CXCL16 is shed from the cell surface by ADAM10, thus, blockade of ADAM10 decreases the CXCL16 concentration $(27,40,41)$.

To assess the effect of proinflammatory cytokines on CXCL16 expression by pancreatic cancer cells, four cell lines were stimulated for $24 \mathrm{~h}$ with low doses of TNF $\alpha, \mathrm{IFN} \gamma$ or a combination of both. Stimulation with the proinflammatory cytokines led to an increase of soluble CXCL16 in cell culture supernatants. In detail, stimulation with $\mathrm{TNF} \alpha$ induced a 1.2-1.7-fold increase of CXCL16, whereas stimulation with IFN $\gamma$ induced a 1.1-2.0-fold increase of CXCL16 in cell culture supernatants. In all four cell lines, a combination of TNF $\alpha$ and IFN $\gamma$ stimulation further increased soluble CXCL16 levels with an overall 1.3-3.1-fold elevation compared to unstimulated cells (Fig. 6A-D).

The liberation of soluble CXCL16 by PDAC cells is dependent on shedding of the membrane-bound CXCL16 fraction by ADAM10. ADAM10 mRNA expression was assessed by qRT-PCR after siRNA transfection to confirm silencing of the target gene. In the evaluated PDAC cell lines (BxPC3, COLO-357), transfection with both ADAM10 siRNA oligonucleotides led to a significant reduction in ADAM10 expression levels (Fig. 7A and B). Measurement of CXCL16 concentrations in cell culture supernatants by ELISA revealed a significant reduction in CXCL16 protein levels after ADAM10 siRNA transfection compared to controls (Fig. 7C and D).

CXCL16 as a potential marker in patients with CP and $P D A C$. So far, no accurate diagnostic markers for pancreatic diseases have been established. Serum markers, such as CEA and CA19-9 are used for monitoring disease, in particular 
A

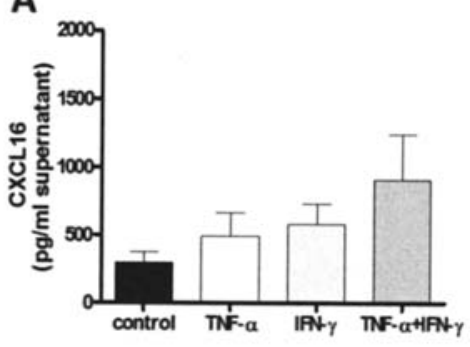

C

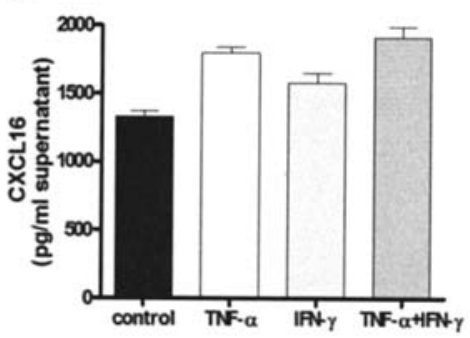

B

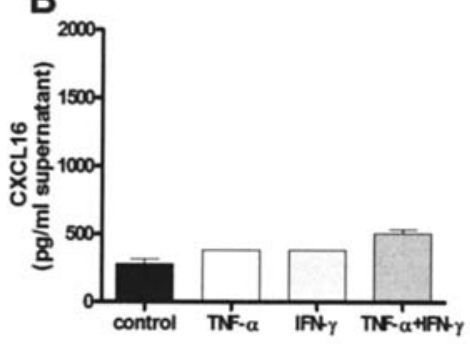

D

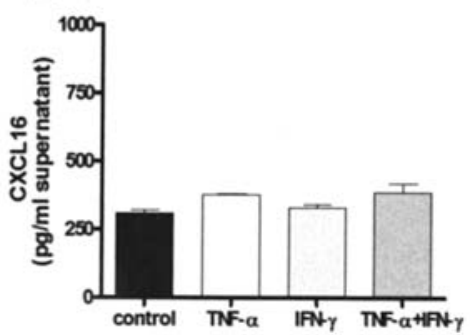

Figure 6. Effect of stimulation of pancreatic cancer cells with proinflammatory cytokines on concentration of soluble CXCL16 in cell culture supernatants. Four different pancreatic cancer cell lines, CAPAN-1 (A), BxPC3 (B), COLO-357 (C), and T3M4 (D), were stimulated with tumor-necrosis factor $\alpha$ (TNF $\alpha$; $1 \mathrm{ng} / \mathrm{ml}$ ), interferon $\gamma(\mathrm{IFN} \gamma ; 1 \mathrm{ng} / \mathrm{ml})$ or the combination of both cytokines for $24 \mathrm{~h}$. Supernatants were collected and CXCL16 ELISA was performed. Data are presented as mean \pm SEM of two independent experiments.

A

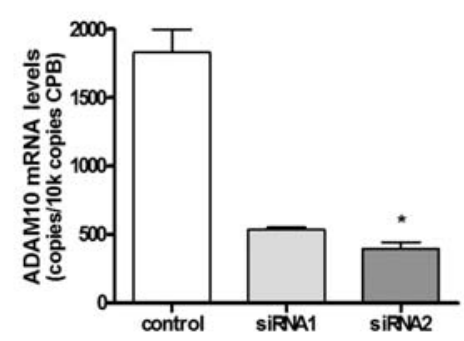

C

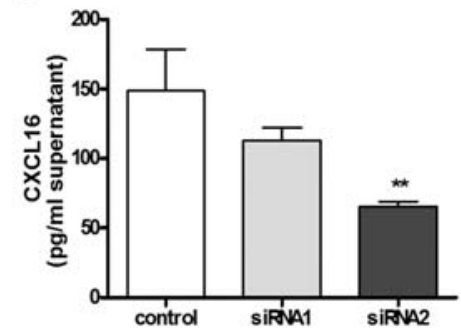

B

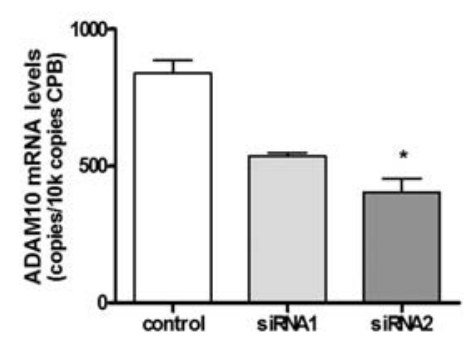

D

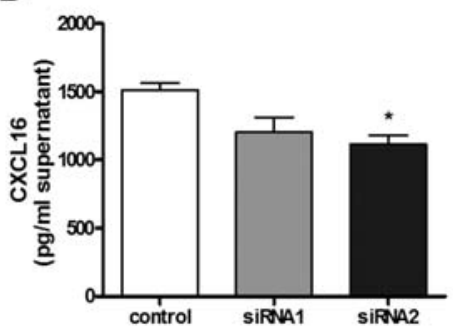

Figure 7. ADAM10 siRNA transfection and determination of the effect on soluble CXCL16 levels in PDAC cells. Transfection with ADAM10 siRNA in BxPC3 (A) and COLO-357 (B) PDAC cells was confirmed by qRT-PCR. Both siRNA oligonucleotides significantly reduced ADAM10 mRNA transcripts (Kruskal-Wallis test, $\mathrm{P}=0.03$; siRNA2 versus control: ${ }^{*} \mathrm{P}<0.05$ ). The effect of ADAM10 silencing on soluble CXCL16 levels was determined by performing a CXCL16 ELISA of cell culture supernatantant; here, a significant reduction in CXCL16 levels occurred in BxPC3 (C) cells (Kruskal-Wallis test, $\mathrm{P}=0.003$; siRNA2 versus control, ${ }^{* *} \mathrm{P}<0.01$ ) and COLO-357 (D) cells (Kruskal-Wallis test, $\mathrm{P}=0.02$; siRNA versus control, ${ }^{*} \mathrm{P}<0.05$ ).

during chemotherapy and following surgery $(42,43)$. Recently, other proteins, such as REG4 and amyloid A have been evaluated $(44,45)$. CXCL16 is expressed by PDAC cells and upregulated in $\mathrm{CP}$ and PDAC tissues. The serum levels of soluble CXCL16 might serve as a diagnostic or follow-up marker in pancreatic diseases.

In order to evaluate the protein levels of CXCL16 in patients with pancreatic cancer, as a potential marker, the concentration of soluble CXCL16 was measured in serum samples of patients with PDAC $(n=80), C P(n=20)$ and in healthy donors $(n=20)$ (serving as controls). Serum ELISA revealed significantly higher CXCL16 levels in patients with CP compared to healthy controls (CP: $1940 \pm 192 \mathrm{pg} / \mathrm{ml}$ versus controls: $1202 \pm 50 \mathrm{pg} / \mathrm{ml} ; \mathrm{P}<0.01)$. Patients with PDAC had 2-fold higher CXCL16 serum levels compared to healthy controls (PDAC: $2462 \pm 120 \mathrm{pg} / \mathrm{ml}$ versus controls: 


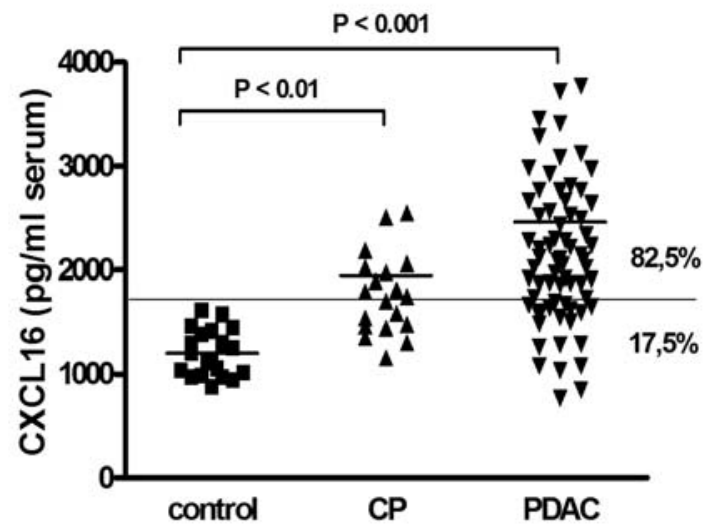

A

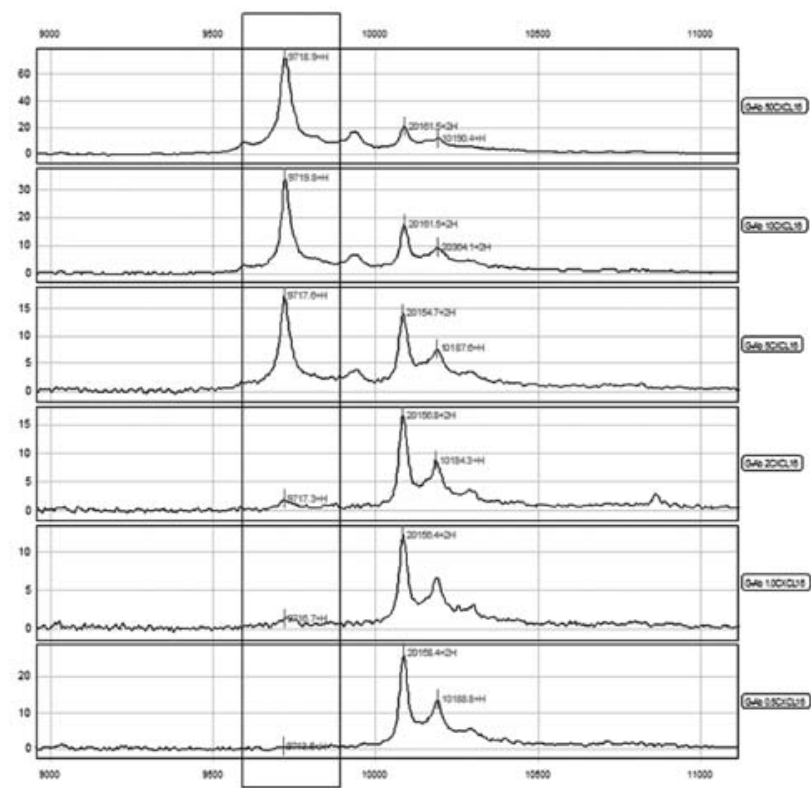

C

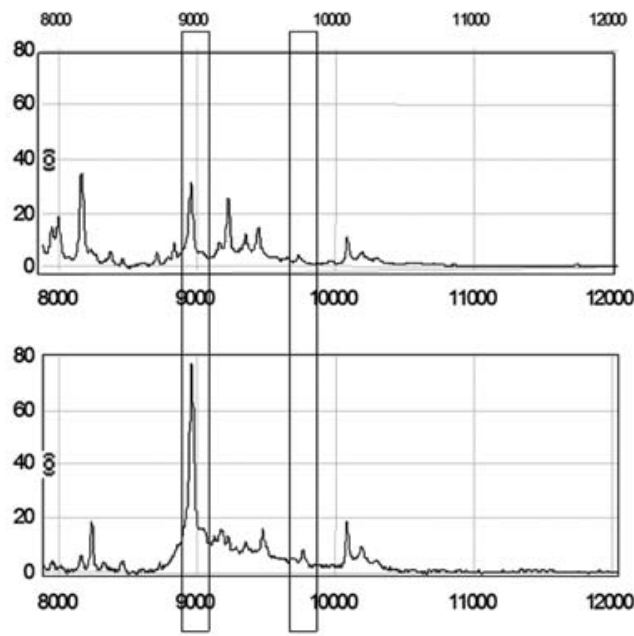

$202 \pm 50 \mathrm{pg} / \mathrm{ml} ; \mathrm{P}<0.001)$ with $82.5 \%$ of the PDAC samples revealing higher CXCL16 levels than the highest value measured in the control group (Fig. 8).
Figure 8. Serum levels of soluble CXCL16 in patients with pancreatic cancer (PDAC) and chronic pancreatitis (CP) compared to healthy controls. Serum levels of CXCL16 in patients with PDAC $(n=80), C P(n=20)$, and healthy controls $(n=20)$ were measured using a commercially available CXCL16 ELISA kit. The results are presented as single values and median (horizontal line in each group). There was a significant elevation of CXCL16 serum levels in CP and PDAC compared to the control group (CP versus control, $\mathrm{P}<0.01$; PDAC versus control, $\mathrm{P}<0.001)$. Of the PDAC samples, $82.5 \%$ revealed higher CXCL16 serum levels than the highest measured value of a healthy donor (horizontal line).

B

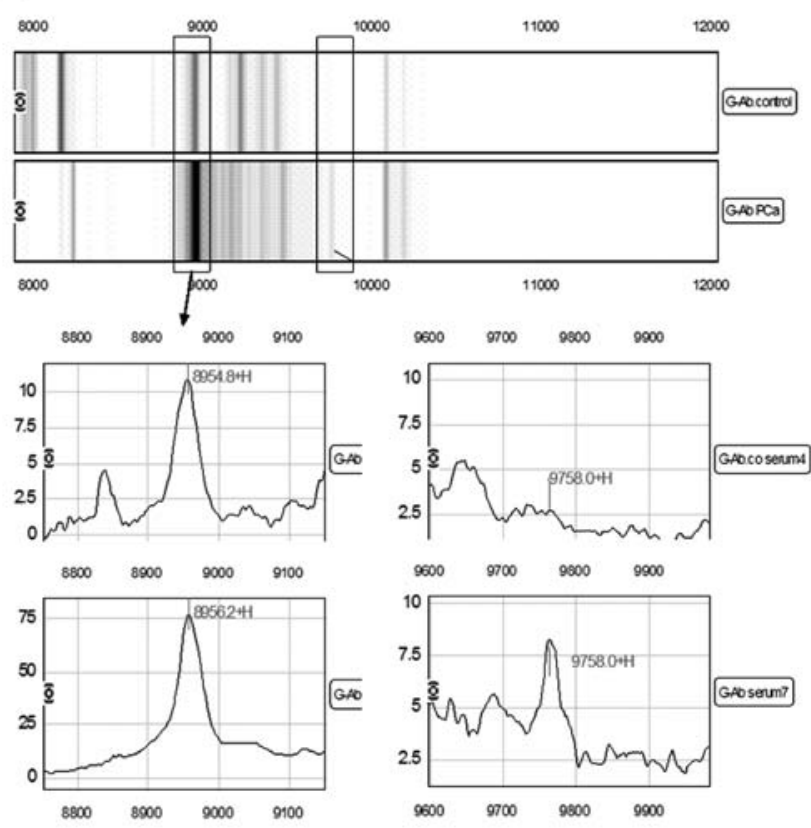

Figure 9. Soluble CXCL16 in patients with pancreatic cancer (PDAC) compared to healthy controls. A titration curve was established to determine the detection limit for human CXCL16 using a PS20 array coupled with protein $\mathrm{G}$ and anti-human CXCL16 antibody. Boxed area shows at m/z 9717 the decline of recombinant human CXCL16 intensity. The amount of CXCL16 loaded on each spot is indicated on the right at the individual spectrum $(0.5$, $1,2,5,10$, and $50 \mathrm{ng} / \mathrm{spot}$ ) (A). A representative gel view of the SELDITOF immunoassay of serum samples from PDAC patients and healthy donors serving as controls are presented. The two boxed regions near $9000 \mathrm{Da}$ and $9800 \mathrm{Da}$ indicate distinct peaks present in the PDAC patient (B). Enlargement of the left and right boxed areas indicating $\mathrm{m} / \mathrm{z}$ values and the intensities of the peaks $(\mathrm{C})$.

For SELDI-TOF mass spectrometry, all components used for the preparation of the PS20-protG-Ab chip array were first tested for purity on NP20 chips. Protein G and the 
antibodies were of good quality and the recombinant human CXCL16 revealed albumin and negligible traces of other proteins (results not shown). The detection limit for the recombinant chemokine using the Protein G-anti-CXCL16 immobilized on PS20 array was set at $0.5 \mathrm{ng} / \mathrm{spot}$ (Fig. 9A).

As the next step, analysis of serum CXCL16 in samples of patients with PDAC $(n=8)$ and healthy controls $(n=8)$ was performed. After exclusion of peaks with low signal-to-noise ratio and peaks from differentially charged proteins, two significant peaks were obtained from the spectra profiled on PS20GAb ProteinChip arrays. As an example, the distribution of signal intensities for the two peaks at $\mathrm{m} / \mathrm{z} 8956$ and $\mathrm{m} / \mathrm{z} 9760$ in control and PDAC serum is given (Fig. 9B). The average peak intensities at m/z 8956 and m/z 9760 were compared between the two groups revealing a 3 -fold and 2 -fold increase in intensity in PDAC samples compared to controls (Fig. 9C).

\section{Discussion}

Pancreatic ductal adenocarcinoma (PDAC) is characterised by its aggressive behaviour and its substantial changes to the local tumor microenvironment. Here in particular, immune cells, fibroblasts and endocrine cells are involved in an intense interplay with the PDAC cells (9). The attraction and accumulation of inflammatory cells, induced by chemotactic stimuli from the cancer cells, contributes to the metastatic capacity of the tumor by influencing the invasiveness and the angiogenic activity of PDAC cells $(10,46)$. The transmembrane CXC chemokine CXCL16 and its receptor CXCR6 might be involved in the regulation of these processes, in particular as the chemokine is shed from the cell surface by members of ADAMs, which are expressed in malignant tumors and are involved in the regulation of tumor growth and invasiveness (47).

First, we examined a distinct overexpression of CXCL16 and CXCR6 at the mRNA and protein levels in PDAC and CP compared to normal pancreas. CXCL16 and CXCR6 expression in normal pancreas tissue displayed a narrow range of mRNA levels, whereas $\mathrm{CP}$ and PDAC tissues revealed a wider range of mRNA expression levels of the chemokines and the receptor, thus reflecting the more heterogenous composition of diseased pancreatic tissues compared to normal tissue samples with a large variation in the amount of ductal pancreatic cells, acinar cells, and infiltrated inflammatory cells as well as in the degree of the desmoplastic reaction including extracellular matrix and fibroblasts. In CP and PDAC, CXCL16 and CXCR6 were moderately to strongly expressed in cancer cells and tubular complexes as evaluated by immunohistochemistry, explaining the variety of mRNA expression levels in bulk $\mathrm{CP}$ and PDAC samples with different percentages of tumor cells and tubular complexes, as well as immune cells within the sample.

In contrast to reports of proliferative effects of CXCL16 on human umbilical vein endothelial cells (48), trophoblasts (38) and malignant glioma cells (30), we could not demonstrate a direct induction or autocrine stimulation of cell growth in human pancreatic cancer cells in vitro after doseand time-dependent stimulation with exogenous CXCL16. Still, CXCL16 significantly increased the invasiveness of pancreatic cancer cells in a standardized Matrigel assay. This reveals an autocrine modulatory effect in the regulation of local mobility of tumor cells leading to an increased metastatic potential.

CXCL16 in its membrane-bound form functions as a strong adhesion molecule (49-51), supporting the idea that shedding of CXCL16 from the tumor cell surface into the periphery might corroborate the hypothesis of a regulation of PDAC invasion by CXCL16. Here, in particular the blockade of the 'CXCL16 sheddase' ADAM10 by specific inhibitors has been shown to be a promising tool in the regulation of CXCL16 functions $(27,40)$. In our study, silencing of ADAM10 using siRNA transfection induced a distinct reduction of soluble CXCL16 production by PDAC cells.

Stimulation with $\mathrm{TNF} \alpha$ and IFN $\gamma$ induced an increase of soluble CXCL16 in PDAC cell culture supernatants in glioma cells (30). These proinflammatory cytokines, which are secreted in vivo by inflammatory cells, are also able to induce an upregulation of soluble CXCL16 in PDAC cells in vitro, further supporting the interplay between pancreatic cancer cells and their microenvironment with infiltrated immune cells (46). This inflammatory process might be the source of the systemic upregulation of CXCL16 in the serum of patients with PDAC, as determined by ELISA and confirmed by SELDI-TOF. Here, the CXCL16 might attract tumor cells to other organ sites, not only increasing local invasiveness, but also metastatic spread. In addition, as soluble CXCL16 serves as a chemoattractant for CXCR6-positive immune cells, the secretion of CXCL16 by tumor cells leads to maintenance of the tumor-immune system interaction, by attracting inflammatory cells to the tumor microenvironment (52). Since not only PDAC cancer cells but other inflammatory cells are able to express pro-angiogenic growth factors, an accumulation of inflammatory cells enables the PDAC to establish a tumor-supportive milieu $(46,53)$.

In addition, PDAC patients showed significant higher serum CXCL16 levels compared to healthy controls, leading to the potential function of CXLC16 as a marker for PDAC progression, at least for monitoring the progression of the disease under chemotherapy or the occurrence of recurrent disease in the follow-up after surgical resections. However, it has been shown that CXCL16 is also upregulated in patients with rheumatoid arthritis (54) and has been used as serum marker for the progress of inflammatory bowel disease (55). Thus, the value of CXCL16 in combination with other serum parameters in the monitoring of patients with PDAC should be further evaluated.

In conclusion, the axis of CXCL16 and its receptor CXCR6 as well as shedding of membrane-bound CXCL16 from the surface of PDAC cells are involved in the pathogenesis of pancreatic cancer. CXCL16 increases invasiveness of PDAC cells and might play an important role in the tumor-immune cell interaction in the tumor microenvironment. It has been shown that inhibition of CXCL16 led to an attenuation of inflammatory and progressive phases of glomerulonephritis (56) and to a reduced infiltration of inflammatory cells and bone destruction in rheumatoid arthritis (57). A possible treatment influencing interplay between CXCL16, ADAM10 and the host, could serve as a target in multimodal treatment concepts in pancreatic cancer in the future. 


\section{References}

1. Jemal A, Siegel R, Ward E, Murray T, Xu J and Thun MJ: Cancer statistics, 2007. CA Cancer J Clin 57: 43-66, 2007.

2. Li D, Xie K, Wolff R and Abbruzzese JL: Pancreatic cancer. Lancet 363: 1049-1057, 2004

3. Friess H, Ding J, Kleeff J, Fenkell L, Rosinski JA, Guweidhi A, Reidhaar-Olson JF, Korc M, Hammer J and Buchler MW: Microarray-based identification of differentially expressed growth- and metastasis-associated genes in pancreatic cancer. Cell Mol Life Sci 60: 1180-1199, 2003.

4. Garcea G, Neal CP, Pattenden CJ, Steward WP and Berry DP: Molecular prognostic markers in pancreatic cancer: a systematic review. Eur J Cancer 41: 2213-2236, 2005

5. Hruban RH: Pancreatic cancer: from genes to patient care. J Gastrointest Surg 5: 583-587, 2001

6. Laheru D and Jaffee EM: Immunotherapy for pancreatic cancer science driving clinical progress. Nat Rev Cancer 5: 459-467, 2005.

7. De Visser KE, Eichten A and Coussens LM: Paradoxical roles of the immune system during cancer development. Nat Rev Cancer 6: 24-37, 2006

8. Zou W: Immunosuppressive networks in the tumour environment and their therapeutic relevance. Nat Rev Cancer 5: 263-274, 2005.

9. Kleeff J, Beckhove P, Esposito I, Herzig S, Huber PE, Lohr JM and Friess H: Pancreatic cancer microenvironment. Int J Cancer 121: 699-705, 2007.

10. Welsch T, Kleeff $\mathbf{J}$ and Friess H: Molecular pathogenesis of pancreatic cancer: advances and challenges. Curr Mol Med 7: 504-521, 2007.

11. Feurino LW, Fisher WE, Bharadwaj U, Yao Q, Chen C and Li M: Current update of cytokines in pancreatic cancer: pathogenic mechanisms, clinical indication, and therapeutic values. Cancer Invest 24: 696-703, 2006.

12. Erkan M, Kleeff J, Gorbachevski A, Reiser C, Mitkus T, Esposito I, Giese T, Buchler MW, Giese NA and Friess H: Periostin creates a tumor-supportive microenvironment in the pancreas by sustaining fibrogenic stellate cell activity. Gastroenterology 132: 1447-1464, 2007.

13. Balkwill F: Cancer and the chemokine network. Nat Rev Cancer 4: 540-550, 2004

14. Scotton CJ, Wilson JL, Milliken D, Stamp G and Balkwill FR: Epithelial cancer cell migration: a role for chemokine receptors? Cancer Res 61: 4961-4965, 2001.

15. Ben Baruch A: The multifaceted roles of chemokines in malignancy. Cancer Metastasis Rev 25: 357-371, 2006.

16. Strieter RM, Burdick MD, Mestas J, Gomperts B, Keane MP and Belperio JA: Cancer CXC chemokine networks and tumour angiogenesis. Eur J Cancer 42: 768-778, 2006.

17. Zlotnik A: Chemokines and cancer. Int J Cancer 119: 2026-2029, 2006.

18. Hedin KE: Chemokines: new, key players in the pathobiology of pancreatic cancer. Int J Gastrointest Cancer 31: 23-29, 2002.

19. Monti P, Marchesi F, Reni M, Mercalli A, Sordi V, Zerbi A, Balzano G, Di Carlo V, Allavena P and Piemonti L: A comprehensive in vitro characterization of pancreatic ductal carcinoma cell line biological behavior and its correlation with the structural and genetic profile. Virchows Arch 445: 236-247, 2004.

20. Wente MN, Keane MP, Burdick MD, Friess H, Buchler MW, Ceyhan GO, Reber HA, Strieter RM and Hines OJ: Blockade of the chemokine receptor CXCR2 inhibits pancreatic cancer cellinduced angiogenesis. Cancer Lett 241: 221-227, 2006.

21. Kuwada Y, Sasaki T, Morinaka K, Kitadai Y, Mukaida N and Chayama K: Potential involvement of IL-8 and its receptors in the invasiveness of pancreatic cancer cells. Int J Oncol 22: 765-771, 2003.

22. Shi Q, Abbruzzese JL, Huang S, Fidler IJ, Xiong Q and Xie K: Constitutive and inducible interleukin 8 expression by hypoxia and acidosis renders human pancreatic cancer cells more tumorigenic and metastatic. Clin Cancer Res 5: 3711-3721, 1999.

23. Koshiba T, Hosotani R, Miyamoto Y, Ida J, Tsuji S, Nakajima S, Kawaguchi M, Kobayashi H, Doi R, Hori T, Fujii N and Imamura M: Expression of stromal cell-derived factor 1 and CXCR4 ligand receptor system in pancreatic cancer: a possible role for tumor progression. Clin Cancer Res 6: 3530-3535, 2000.

24. Wehler T, Wolfert F, Schimanski CC, Gockel I, Herr W, Biesterfeld S, Seifert JK, Adwan H, Berger MR, Junginger T, Galle PR and Moehler M: Strong expression of chemokine receptor CXCR4 by pancreatic cancer correlates with advanced disease. Oncol Rep 16: 1159-1164, 2006.
25. Wente MN, Mayer C, Gaida MM, Michalski CW, Giese T, Bergmann F, Giese NA, Buchler MW and Friess H: CXCL14 expression and potential function in pancreatic cancer. Cancer Lett 259: 209-217, 2008.

26. Matloubian M, David A, Engel S, Ryan JE and Cyster JG: A transmembrane CXC chemokine is a ligand for HIV-coreceptor Bonzo. Nat Immunol 1: 298-304, 2000.

27. Abel S, Hundhausen C, Mentlein R, Schulte A, Berkhout TA, Broadway N, Hartmann D, Sedlacek R, Dietrich S, Muetze B, Schuster B, Kallen KJ, Saftig P, Rose-John S and Ludwig A: The transmembrane CXC-chemokine ligand 16 is induced by IFN-gamma and TNF-alpha and shed by the activity of the disintegrin-like metalloproteinase ADAM10. J Immunol 172: 6362-6372, 2004.

28. Shimaoka T, Nakayama T, Fukumoto N, Kume N, Takahashi S, Yamaguchi J, Minami M, Hayashida K, Kita T, Ohsumi J, Yoshie $\mathrm{O}$ and Yonehara S: Cell surface-anchored SRPSOX/CXC chemokine ligand 16 mediates firm adhesion of CXC chemokine receptor 6-expressing cells. J Leukoc Biol 75: 267-274, 2004.

29. Wilbanks A, Zondlo SC, Murphy K, Mak S, Soler D, Langdon P, Andrew DP, Wu L and Briskin M: Expression cloning of the STRL33/ BONZO/TYMSTRligand reveals elements of CC, CXC, and CX3C chemokines. J Immunol 166: 5145-5154, 2001

30. Ludwig A, Schulte A, Schnack C, Hundhausen C, Reiss K, Brodway N, Held-Feindt J and Mentlein R: Enhanced expression and shedding of the transmembrane chemokine CXCL16 by reactive astrocytes and glioma cells. J Neurochem 93: 1293-1303, 2005.

31. Wuttge DM, Zhou X, Sheikine Y, Wagsater D, Stemme V, Hedin U, Stemme S, Hansson GK and Sirsjo A: CXCL16/SRPSOX is an interferon-gamma-regulated chemokine and scavenger receptor expressed in atherosclerotic lesions. Arterioscler Thromb Vasc Biol 24: 750-755, 2004.

32. Hojo S, Koizumi K, Tsuneyama K, Arita Y, Cui Z, Shinohara K, Minami T, Hashimoto I, Nakayama T, Sakurai H, Takano Y, Yoshie O, Tsukada K and Saiki I: High-level expression of chemokine CXCL16 by tumor cells correlates with a good prognosis and increased tumor-infiltrating lymphocytes in colorectal cancer. Cancer Res 67: 4725-4731, 2007.

33. Erkan M, Kleeff J, Esposito I, Giese T, Ketterer K, Buchler MW, Giese NA and Friess H: Loss of BNIP3 expression is a late event in pancreatic cancer contributing to chemoresistance and worsened prognosis. Oncogene 24: 4421-4432, 2005.

34. Valkovskaya N, Kayed H, Felix K, Hartmann D, Giese NA, Osinsky SP, Friess H and Kleeff J: ADAM8 expression is associated with increased invasiveness and reduced patient survival in pancreatic cancer. J Cell Mol Med 11: 1162-1174, 2007.

35. Takamori H, Oades ZG, Hoch OC, Burger M and Schraufstatter IU: Autocrine growth effect of IL-8 and GROalpha on a human pancreatic cancer cell line, Capan-1. Pancreas 21: 52-56, 2000.

36. Kamohara H, Takahashi M, Ishiko T, Ogawa $M$ and Baba H: Induction of interleukin-8 (CXCL-8) by tumor necrosis factoralpha and leukemia inhibitory factor in pancreatic carcinoma cells: Impact of CXCL-8 as an autocrine growth factor. Int J Oncol 31: 627-632, 2007

37. Mori T, Doi R, Koizumi M, Toyoda E, Ito D, Kami K, Masui T, Fujimoto K, Tamamura H, Hiramatsu K, Fujii N and Imamura M: CXCR4 antagonist inhibits stromal cell-derived factor 1-induced migration and invasion of human pancreatic cancer. Mol Cancer Ther 3: 29-37, 2004

38. Huang Y, Zhu XY, Du MR, Wu X, Wang MY and Li DJ: Chemokine CXCL16, a scavenger receptor, induces proliferation and invasion of first-trimester human trophoblast cells in an autocrine manner. Hum Reprod 21: 1083-1091, 2006.

39. Wagsater D, Olofsson PS, Norgren L, Stenberg B and Sirsjo A The chemokine and scavenger receptor CXCL16/SR-PSOX is expressed in human vascular smooth muscle cells and is induced by interferon gamma. Biochem Biophys Res Commun 325: 1187-1193, 2004.

40. Ludwig A, Hundhausen C, Lambert MH, Broadway N, Andrews RC, Bickett DM, Leesnitzer MA and Becherer JD: Metalloproteinase inhibitors for the disintegrin-like metalloproteinases ADAM10 and ADAM17 that differentially block constitutive and phorbol ester-inducible shedding of cell surface molecules. Comb Chem High Throughput Screen 8: 161-171, 2005

41. Gough PJ, Garton KJ, Wille PT, Rychlewski M, Dempsey PJ and Raines EW: A disintegrin and metalloproteinase 10-mediated cleavage and shedding regulates the cell surface expression of CXC chemokine ligand 16. J Immunol 172: 3678-3685, 2004. 
42. Ni XG, Bai XF, Mao YL, Shao YF, Wu JX, Shan Y, Wang CF, Wang J, Tian YT, Liu Q, Xu DK and Zhao P: The clinical value of serum CEA, CA19-9, and CA242 in the diagnosis and prognosis of pancreatic cancer. Eur J Surg Oncol 31: 164-169, 2005.

43. Yasue M, Sakamoto J, Teramukai S, Morimoto T, Yasui K, Kuno N, Kurimoto K and Ohashi Y: Prognostic values of preoperative and postoperative CEA and CA19.9 levels in pancreatic cancer. Pancreas 9: 735-740, 1994.

44. Takehara A, Eguchi H, Ohigashi H, Ishikawa O, Kasugai T, Hosokawa M, Katagiri T, Nakamura Y and Nakagawa H: Novel tumor marker REG4 detected in serum of patients with resectable pancreatic cancer and feasibility for antibody therapy targeting REG4. Cancer Sci 97: 1191-1197, 2006.

45. Yokoi K, Shih LC, Kobayashi R, Koomen J, Hawke D, Li D, Hamilton SR, Abbruzzese JL, Coombes KR and Fidler IJ: Serum amyloid A as a tumor marker in sera of nude mice with orthotopic human pancreatic cancer and in plasma of patients with pancreatic cancer. Int J Oncol 27: 1361-1369, 2005.

46. Esposito I, Menicagli M, Funel N, Bergmann F, Boggi U, Mosca F, Bevilacqua G and Campani D: Inflammatory cells contribute to the generation of an angiogenic phenotype in pancreatic ductal adenocarcinoma. J Clin Pathol 57: 630-636, 2004.

47. Mochizuki S and Okada Y: ADAMs in cancer cell proliferation and progression. Cancer Sci 98: 621-628, 2007.

48. Zhuge X, Murayama T, Arai H, Yamauchi R, Tanaka M, Shimaoka T, Yonehara S, Kume N, Yokode M and Kita T: CXCL16 is a novel angiogenic factor for human umbilical vein endothelial cells. Biochem Biophys Res Commun 331: 1295-1300, 2005

49. Hundhausen C, Schulte A, Schulz B, Andrzejewski MG, Schwarz N, von Hundelshausen P, Winter U, Paliga K, Reiss K, Saftig P, Weber C and Ludwig A: Regulated shedding of transmembrane chemokines by the disintegrin and metalloproteinase 10 facilitates detachment of adherent leukocytes. J Immunol 178: 8064-8072, 2007.
50. Hara T, Katakai T, Lee JH, Nambu Y, Nakajima-Nagata N, Gonda H, Sugai M and Shimizu A: A transmembrane chemokine, CXC chemokine ligand 16, expressed by lymph node fibroblastic reticular cells has the potential to regulate $\mathrm{T}$ cell migration and adhesion. Int Immunol 18: 301-311, 2006.

51. Scholz F, Schulte A, Adamski F, Hundhausen C, Mittag J, Schwarz A, Kruse ML, Proksch E and Ludwig A: Constitutive expression and regulated release of the transmembrane chemokine CXCL16 in human and murine skin. J Invest Dermatol 127: 1444-1455, 2007.

52. Koizumi K, Hojo S, Akashi T, Yasumoto $\mathrm{K}$ and Saiki $\mathrm{I}$ Chemokine receptors in cancer metastasis and cancer cellderived chemokines in host immune response. Cancer Sci 98: $1652-1658,2007$

53. Bingle L, Brown NJ and Lewis CE: The role of tumour-associated macrophages in tumour progression: implications for new anticancer therapies. J Pathol 196: 254-265, 2002.

54. Kageyama Y, Torikai E and Nagano A: Anti-tumor necrosis factor-alpha antibody treatment reduces serum CXCL16 levels in patients with rheumatoid arthritis. Rheumatol Int 27: 467-472, 2007.

55. Lehrke M, Konrad A, Schachinger V, Tillack C, Seibold F, Stark R, Parhofer KG and Broedl UC: CXCL16 is a surrogate marker of inflammatory bowel disease. Scand J Gastroenterol 43: 283-288, 2007.

56. Garcia GE, Truong LD, Li P, Zhang P, Johnson RJ, Wilson CB and Feng L: Inhibition of CXCL16 attenuates inflammatory and progressive phases of anti-glomerular basement membrane antibody-associated glomerulonephritis. Am J Pathol 170: 1485-1496, 2007.

57. Nanki T, Shimaoka T, Hayashida K, Taniguchi K, Yonehara S and Miyasaka N: Pathogenic role of the CXCL16-CXCR6 pathway in rheumatoid arthritis. Arthritis Rheum 52: 3004-3014, 2005 . 